\title{
ForCe MAJEURE in CANAdian LAW
}

\author{
MichaEl P THEROUX AND APRIL D GROSSE*
}

Force majeure clauses are intended to allocate risk for future events that, if they occur, will affect the ability of one party to perform its obligations under the contract. This article undertakes a comprehensive review of the Canadian law of force majeure and its application in the energy sector. The article begins by examining the legal foundations of force majeure found in the common law, Canadian jurisprudence, and other legal regimes. It then describes the operation of a force majeure clause and analyzes how such a clause is likely to be interpreted by the courts. Along with analyzing specific aspects of force majeure, such as triggering events, foreseeability and control, and issues relating to impact and causation, the authors incorporate many practical suggestions that will be useful to drafters of force majeure clauses.
Les clauses de force majeure ont pour but de prévoir le risque d'événements futurs qui, le cas échéant, auront une incidence sur la capacité de la partie de respecter ses obligations en vertu du contrat. Cet article entreprend un examen complet du droit canadien en matière de force majeure et la manière dont il est appliqué dans le secteur énergétique. L'article commence par examiner les principes juridiques de la force majeure telle qu'ils existent dans la common law, la jurisprudence canadienne, et autre régime juridique. Il décrit ensuite le fonctionnement d'une clause de force majeure et en analyse l'interprétation probable par les tribunaux. Tout en tenant compte d'aspects précis de la force majeure, comme les événements déclencheurs, la prévisibilité, et les contrôles ainsi que les questions relatives à l'impact et la cause, les auteurs incorporent de nombreuses suggestions pratiques pour les rédacteurs de clauses de force majeure.

\section{TABLE OF CONTENTS}

I. INTRODUCTION . . . . . . . . . . . . . . . . . . . . . . . . . . . . . . 397

II. LEGAL CONTEXT FOR FORCE MAJEURE . . . . . . . . . . . . . . . 398

A. Why CONTEXT IS IMPORTANT . . . . . . . . . . . . . . . . . . . 398

B. FRUSTRATION . . . . . . . . . . . . . . . . . . . . . 398

C. Other Legal Regimes $\ldots \ldots \ldots \ldots \ldots \ldots \ldots \ldots \ldots \ldots \ldots$

D. LACK OF CASE LAW . . . . . . . . . . . . . . . . . . . . 401

III. Force MAJeure Clauses . . . . . . . . . . . . . . . . . . . . . . . . . . . 401

A. Triggering Events . . . . . . . . . . . . . . . . . . . . . . . . . 402

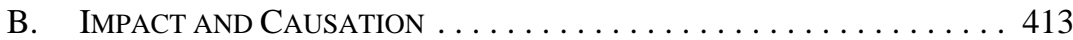

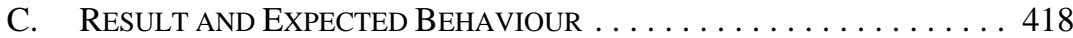

IV. Concluding REMARKS . . . . . . . . . . . . . . . . . . . . . . 425

\section{INTRODUCTION}

Most, if not all, lawyers working in the Canadian energy sector have at least a working knowledge of force majeure clauses and their role in common contracts. However, many will go years without encountering a force majeure event of particular significance or one that requires extensive consideration of the application of these clauses and the law behind them. In an increasingly global marketplace, events, such as the Deepwater Horizon blowout in the Gulf of Mexico, including the subsequent ripple of regulatory reviews, and the recent earthquake and tsunami events in Japan, may leave Canadian lawyers receiving and issuing

Partners in the litigation department at Bennett Jones LLP, Calgary, Alberta. The authors gratefully acknowledge the assistance of Thomas McInerney, Matthew Macdonald, and Bryan West in preparation of this article. 
more force majeure notices than they are accustomed to, or at least wondering where their clients would stand in analogous circumstances. This presents an opportunity to undertake a comprehensive review of the Canadian law of force majeure and its application in the energy sector. ${ }^{1}$

\section{LEGAL CONTEXT FOR FORCE MAJEURE}

\section{A. WHY CONTEXT IS IMPORTANT}

Force majeure clauses are intended to allocate risk for future events that, if they occur, will affect the ability of one party to perform its obligations under the contract. As Justice Kerans of the Alberta Court of Appeal said: "The office of the clause is to protect the parties from events outside normal business risk."”

When considering a force majeure clause, and particularly when drafting, it is helpful to know how the common law would address the contemplated supervening events. In other words, what is the clause supplanting or supplementing? The default doctrine of the common law is impossibility and frustration. It is arguable that the courts have, at times, been influenced by the law of frustration when interpreting force majeure clauses.

\section{B. FRUSTRATION}

The traditional common law position was that contracts were absolute. The parties were bound to perform even if performance had become impossible. The courts took the view that the party whose performance was rendered impossible could have provided against the contingency by agreement, and if it did not, then it had to perform or be liable for breach. The case generally seen as the source of the "absolute liability" doctrine is Paradine $v$ Jane. ${ }^{3}$ There, a landlord sued his tenant for arrears of rent. The tenant defended on the basis that he had been ejected from the land by an enemy force such that he received no benefit from the lands or the lease. The Court found for the landlord on the basis that there was no exemption set out in the contract, so it was absolute.

The application of the absolute contract doctrine led to results that often seemed unduly harsh, and quite likely inconsistent with the shared assumptions of the parties that underlay the contract, for example, the continued existence of the subject matter of the contract. Gradually, the courts began relaxing the approach to supervening events. In Taylor $v$ Caldwell, ${ }^{4}$ the defendants had agreed to rent out a music hall to the plaintiffs on four specific dates; the plaintiffs were going to give a series of concerts. This purpose was specified in the contract. Before any of the concerts took place, the music hall was destroyed by fire. The plaintiffs claimed against the defendants for the costs they had incurred and for other damage. The Court held:

This article addresses only Canadian common law and not the concept of "force majeure" as it exists in the civil law of Quebec.

Atcor Ltd v Continental Energy Marketing Ltd (1996), 178 AR 372 at para 12 (CA) [Atcor].

[1647] 4 (KB), 82 ER 897 [Paradine].

(1863), 122 ER 309 [Taylor]. 
The principle seems to us to be that, in contracts in which the performance depends on the continued existence of a given person or thing, a condition is implied that the impossibility of performance arising from the perishing of the person or thing shall excuse the performance.

We think, therefore, that the Music Hall having ceased to exist, without fault of either party, both parties are excused, the plaintiffs from taking the gardens and paying the money, the defendants from performing their promise to give the use of the Hall and Gardens and other things. ${ }^{5}$

While Taylor can be reconciled with Paradine on the basis that in Paradine the subject matter of the contract (the land) continued to exist, Taylor is generally seen as the genesis of the doctrine of discharge, commonly known today as "frustration." In this first incarnation, the doctrine was based on the theory of an implied condition in the contract.

Had the law ceased development in 1863, the doctrine of frustration may well have been relatively easy to apply today. However, in the century and a half since the decision of Taylor, the doctrine has been reformulated in a number of instances and applied in circumstances that would not necessarily fit within the "impossibility of performance" or "implied term" concepts set out in Taylor. One of the best known examples is the decision in Krell $v$ Henry. ${ }^{6}$ There, the defendant rented two rooms from the plaintiff for a specified period and paid a deposit. While there was nothing express in the contract, it was apparently understood by both parties that the purpose of the defendant renting the rooms was to watch the coronation procession of Edward VII. When the coronation was postponed, the defendant refused to take the rooms and pay the remainder of the agreed rent. The plaintiff sued for the outstanding balance. ${ }^{7}$ The Court found for the defendant on the basis that while performance was not physically impossible, it was impossible in the sense that a "state of things, going to the root of the contract, and essential to its performance" had ceased to exist. ${ }^{8}$ This version of frustration is often referred to as "frustration of purpose."

The idea that the discharge of performance was based on an implied condition in the contract also came into question in later cases. The more common formulation today in the United Kingdom and Canada is often referred to as the "construction theory" and was espoused as follows by Lord Radcliffe in Davis Contractors Ltd v Fareham Urban District Council:

[F]rustration occurs whenever the law recognises that without default of either party a contractual obligation has become incapable of being performed because the circumstances in which performance is called for would render it a thing radically different from that which was undertaken by the contract. Non haec in foedera veni. It was not this that I promised to do. ${ }^{10}$

Ibid at paras 839-40 [emphasis added].

[1903] 2 KB 740 [Krell].

Ibid at 741 .

Ibid at 748 .

For a discussion of the concept of frustration of purpose, see generally GH Treitel, Frustration and Force Majeure, 2d ed, ch 7 (London: Sweet \& Maxwell, 2004). 
This approach was expressly adopted by the Supreme Court of Canada in Naylor Group Inc $v$ Ellis-Don Construction Ltd. ${ }^{11}$

There have also been rather specific developments of the doctrine in cases of sale of goods and sale of land. ${ }^{12}$

With existing lines of authority applying all of the above versions of frustration, and others, it is easy to understand why reconciling the result from case-to-case can be difficult. Further, even applying the same test to any given set of facts leaves room for uncertainty. Particularly once a dispute has arisen, two parties may have very different views of whether the performance now called for is "radically different" from what was undertaken. While the courts have been careful to state that performance is not radically different where it is simply more expensive or onerous, or the contract has ceased to be advantageous for one party, ${ }^{13}$ the uncertainty associated with the doctrine of frustration leaves many commercial parties wanting to take matters into their own hands to the extent possible with a force majeure clause. Further, throughout the development of the doctrine of frustration, one aspect has remained constant: a finding of frustration fully discharges the obligations of both parties. This blunt and inflexible result is another impetus for force majeure clauses, which allow the parties to fashion a more nuanced legal result for supervening events.

\section{OTHER LEGAL REgIMES}

This article focuses on Canadian common law, supplemented with some examples from British and American law for illustration. However, it is important to note that there is a distinct notion of force majeure in civil law, including in the Civil Code of Québec. ${ }^{14}$ The French text of the Code refers to "force majeure", while the English text refers to "superior force." ${ }^{15}$ Reference to "force majeure" in the Civil Code context is usually a reference to the civil law equivalent to the common law doctrine of frustration, not to an express contractual provision. ${ }^{16}$ This has two obvious implications for Canadian lawyers. First, when reviewing case law that references "force majeure," it is important to distinguish between discussions of a force majeure clause and interpretations of the civil law doctrine. Further, if contracting with a party from Quebec or another civil law jurisdiction, it is important to understand that they may come to the table with the civil law notion of "force majeure" in mind.

Similarly, although American law also had its roots in the UK, the doctrine of discharge developed somewhat differently there than in England, leaving more room for relief in cases of "impracticability" as opposed to "impossibility."17 Further, the American Uniform Commercial Code has provisions that may impact the application of frustration and force majeure. $^{18}$

2001 SCC 58, [2001] 2 SCR 943 at para 53.

See generally GHL Fridman, The Law of Contract in Canada, 5th ed (Toronto: Carswell, 2006) at 66771.

Ibid at 646-47.

SQ 1991, c 64 [Civil Code].

Ibid, s 1470.

Equivalent in the sense of both being "default" positions dealing with supervening events. The two doctrines are not the same.

See e.g. Roy v Stephen Pontiac-Cadillac, Inc, 543 A (2d) 775 (Conn 1988).

$U C C$ § 2-615 (2005). 
The underlying message is not unique to the doctrine of force majeure. When entering international commercial contracts, and particularly where those contracts are governed by foreign law, it is important not to assume that legal concepts in the foreign jurisdiction, even if they have the same name, are identical to their Canadian counterparts.

\section{LACK OF CASE LAW}

The anecdotal observation of the authors is that the topic of force majeure receives a reasonable amount of attention in conference papers and frequently arises in practice, yet there are relatively few Canadian cases interpreting force majeure clauses. While by no means a study of scientific validity, if one performs an online search for "force majeure" in the "summary" field for Canadian cases, and with obvious potential variances depending on the database used, only approximately 219 cases come up. Out of those, at least 75 percent deal with the civil law concept of force majeure as opposed to interpreting contractual force majeure clauses. Taking out a few others that are repetitive or have little significance, one is left with less than 30 decisions. This is surprising, given the prevalence of force majeure clauses in commercial contracts. While it may be that parties are frequently able to resolve their disputes over force majeure on commercial terms, the authors expect that one of the reasons for the lack of case law is the prevalence of arbitration provisions in the same contracts that include force majeure clauses. ${ }^{19}$ This is consistent with the authors' experience in practice. Of course, with most arbitration clauses, both the existence and outcome of a dispute remain confidential. While a discussion about the positive and negative aspects of private dispute resolution is well outside the scope of this article, one consequence is the lack of developing jurisprudence interpreting clauses commonly found in sophisticated commercial agreements.

\section{Force MAJeure Clauses}

As referenced above, force majeure clauses have developed at least in part as a response to the perceived limits of the common law doctrine of frustration. First, a contractual clause should create more certainty than the doctrine of frustration, the application of which is often difficult to predict. Second, handling supervening events by contract allows parties to list those events that would be significant enough to them to warrant a change in one or both parties' obligations; they may include events that would not qualify as frustrating events under the common law and exclude others. Third, the parties may agree by contract on the effect that such events would have on a party's obligation to perform. The law of frustration limits the available relief to the full discharge of both parties' obligations. Less drastic remedies than full discharge, such as suspension of obligations, can be agreed to in advance, and different remedies established for different events.

Parties are generally free to draft the force majeure clause to include the events, and consequences for those events, that they see fit. However, conventional wisdom suggests that a good clause should include at least three elements, and the courts have explicitly agreed. In Atcor, the Alberta Court of Appeal noted that a force majeure clause should address three questions: 
* $\quad$ how broad should be the definition of triggering events;

* what impact must those events have on the party who invokes the clause;

* $\quad$ what effect should invocation have on the [parties' contractual obligations]. ${ }^{20}$

We will address each of these elements in turn below.

\section{A. Triggering EVEnTS}

Force majeure clauses invariably contain a description of events that may give rise to force majeure. Typically, a force majeure clause includes a list of specified events, and a catch-all or basket clause designed to cover events not specifically set out in the list. The length of the list of specific events can vary from clause to clause, as can the breadth of the basket clause. Most modern clauses also qualify potential triggering events, usually by way of the basket clause, by requiring that they be events outside the control of the parties.

Common triggering events specifically referenced in force majeure clauses include:

(1) acts of God, landslide, flood, tempest, washout, fire, lightning, disaster, earthquake, and storm;

(2) actions of military, naval, or civil authority, the Queen's or a public enemy, war, revolution, political disturbance, and terrorism;

(3) civil disturbance;

(4) expropriation, acts or restraints of a governmental body or authority, and failure to obtain a requisite permit or authorization from a governmental authority by reason of any statute, law, or Order-In-Council, or any regulation or order passed or made pursuant thereto or by reason of the order or direction of any administrator, controller, or board, or any governmental department or officer or other authority, or by reason of not being able to obtain any permission or authority required thereby;

(5) unusual delay by common carriers;

(6) sabotage, rebellion, vandalism, riot, blockade, insurrection, strike, lockout, and explosion;

(7) power failure and non-availability of labour, materials service, equipment, goods, or utility; and

(8) epidemic and quarantine. 
Of course, the list of specified events should be tailored to the unique circumstances of a given contract. While precedents are helpful, the real advantage of having a force majeure clause is that it can be used to address situations that would be of particular significance to the parties and their operations. For instance, if one party is dependent on a particular supply source, the parties have to turn their minds to whether the failure of that source will be an event of force majeure. Some of the model forms of the Association of International Petroleum Negotiators provide good examples of optional tailored events of force majeure, including supply and purchasing chain issues. For example: "failure of Gas Transporter to take delivery of and transport Gas, through the Transporter's pipeline system for reasons that would constitute a Force Majeure Event as defined in this Agreement if Gas Transporter were a Party to this Agreement."21

The exact wording of basket clauses varies, but in modern contracts, it generally refers to any other causes beyond the control of the parties. Again, parties will want to consider whether this type of a clause suits their needs. Parties seeking a very broad interpretation may add some form of wording such as "without limitation" or "whether or not similar to the items in the above list" for certainty. On the other hand, a party with a great deal to lose if the other side does not perform may try to bargain for a reduced list of specific events and a narrow basket clause. Broad is not necessarily better. It is also becoming common to put the basket clause up front with a list of specific inclusions. ${ }^{22}$ As long as the substantive wording is clear, it should not matter which goes first.

Another consideration when drafting the definition of events triggering force majeure is whether particular events need to be expressly excluded. This will be particularly important where the basket clause is broad. Common express exceptions include inability to pay and change in financial circumstances. ${ }^{23}$ The very subject matter of the contract may deal with services to be provided in the case of a natural disaster; in that case, the party receiving the services may want it to be absolutely clear that the very disaster on which the contract is premised is not an event of force majeure. While it seems unlikely that this could happen at the drafting stage, or that the clause would be interpreted in such a manner, anomalies do occur when various boilerplate clauses are amassed into a contract without due consideration of how one affects the other.

\section{PRINCIPLES OF INTERPRETATION}

When interpreting force majeure clauses, including the definition of triggering events, the usual rules of contractual interpretation apply. Those include principles such as ejusdem generis and expressio unius, which of course come to mind because of the list-based definition. The former has received particular attention.

Association of International Petroleum Negotiators (AIPN), AIPN Model Form Gas Sales Agreement, "Force Majeure Event" (2006), art 1.1 [AIPN Model Agreement].

22 This approach is used in most of the AIPN and Petroleum Joint Venture Association (PJVA) model forms.

23 Most of the standard energy forms include these restrictions. For example, see Canadian Association of Petroleum Landmen (CAPL) definition of "Force Majeure": "However, lack of finances, changes in a Party's economic circumstances and changes that affect the economic attributes of investments hereunder will not be considered an event of Force Majeure.” CAPL, CAPL Operating Procedure (Calgary: CAPL, 2007) at 6. 
The ejusdem generis rule is that, when interpreting documents containing a list of specific items followed by more general items, the general items will not be interpreted in a broad or wide sense but instead will be limited to the type or class of specific items previously listed. The Supreme Court of Canada applied ejusdem generis in the first major Canadian case on force majeure, Atlantic Paper Stock Ltd v St Anne-Nackawic Pulp and Paper Co Ltd. ${ }^{24}$ The clause read:

St. Anne warrants and represents that its requirements under this contract shall be approximately 15,000 tons a year, and further warrants that in any one year its requirements for Secondary Fibre shall not be less than 10,000 tons, unless as a result of an act of God, the Queen's or public enemies, war, the authority of the law, labour unrest or strikes, the destruction of or damage to production facilities, or the nonavailability of markets for pulp or corrugating medium. ${ }^{25}$

Approximately one year into the contract, St. Anne-Nackawic Pulp and Paper Co Ltd (St. Anne) served notice that it would not be receiving any further deliveries of waste paper. It pleaded the force majeure clause and in particular, the "non-availability of markets for pulp or corrugating medium." 26 The Court said that, reading the clause ejusdem generis, "nonavailability of markets" was limited to an event over which St. Anne had no control, since all the preceding events in the clause were that type of event. ${ }^{27}$

The Court went on to find that St. Anne was in large part the author of its own misfortunes. While it was true that there was a limited market, St. Anne ought to have known this at the time it entered into the contract. St. Anne lacked an effective marketing plan, lacked appreciation of the Canadian market, and had high costs compared to competitors. Nothing had materially changed in the market itself after the contract was signed. ${ }^{28}$ Thus while the market was not economic for St. Anne, that fact was not caused by an event outside St. Anne's control. ${ }^{29}$

It is noteworthy that there was no basket clause in Atlantic Paper. In later cases, the inclusion of a basket clause has defeated the application of ejusdem generis. For example, in Morris $v$ Cam-Nest Developments $L t d,{ }^{30}$ the force majeure clause was contained in two purchase and sale agreements for residential condominiums. The clause contained a list of specific events ("strikes, lock-outs, fire, lightning, tempest, riot, war and unusual delay by common carriers or unavoidable casualties" ${ }^{31}$ ) followed by a basket clause that read "or by any other cause of any kind whatsoever beyond the control of the Vendor." 32 If the vendor was delayed in completing the condominium units by reason of a force majeure event, the vendor was entitled to a reasonable extension in the completion date. ${ }^{33}$

[1976] 1 SCR 580 [Atlantic Paper].

Ibid at 581-82.

Ibid at 581 .

Ibid at 583.

Ibid at 583-87.

Ibid at 587.

(1988), 64 OR (2d) 475.

Ibid at 482.

Ibid.

Ibid. 
The vendor invoked the force majeure clause, arguing that it had been delayed by unusually cold weather followed by strikes among sub-trades. ${ }^{34}$ The purchasers argued that the cold weather (with potential exacerbation by strikes) was not the type of catastrophic, out of the ordinary or unusual event contemplated by the specific events listed in the force majeure clause. The purchasers cited the ejusdem generis principle and its application in Atlantic Paper. ${ }^{35}$

The Court found the ejusdem generis rule inapplicable as a result of the basket clause. ${ }^{36}$ The Court agreed that the vendor's delayed performance was the result of unusually cold weather and the three strikes, and found that these were events of a kind "beyond the reasonable control of the vendor." ${ }^{37}$ The vendor was entitled to an extension in the time to complete the condominium units. ${ }^{38}$

In World Land Ltd v Daon Development Corp, ${ }^{39}$ the Alberta Court of Queen's Bench considered applying the ejusdem generis principle to limit the scope of a basket clause, based on the list of specific triggering events. However, in that case, the Court found that the list of events ("acts of God or of the enemies of Canada, fire or other casualty, war, disaster, riots, strikes, lock-outs or other disturbances" ${ }^{\text {") }}$ ) were not all of the same genus so as to allow application of the rule. Some were acts of nature while others were human based. As the Court said: "To treat them as being of the same genus would be akin to lumping melodrama together with tragedy." ${ }^{41}$ Further the Court noted that the broad basket clause ("any other causes ... beyond the control of the vendors or the purchasers") was intended to mean exactly what it said. ${ }^{42}$

Parties should be aware that while courts are prepared to give effect to a broad definition of force majeure, they will be wary of allowing the clause to become an "escape clause.” The Alberta Court of Appeal in Atcor expressly stated its concern: "This contract offered a very broad list of events.... There is much to be said for that. The event need not be a catastrophe or 'act of God', just something not present in sound business calculations.... But a broad list of force majeure events offers the risk of turning the bargain on its head if it can be used as an escape clause."43

The Court found that if the list of force majeure events was broad, then the other elements of the clause - impact and legal effect — had to be drafted and interpreted so as to put reasonable limits on the application and extent of force majeure: "When the list is broad, one reasonably expects to see in the contract that the event is tied to meaningful consequences."44 The Court's advice on the other elements of the force majeure clause is addressed below.

Ibid at 478.

Ibid at $484-85$.

Ibid at 485 .

Ibid at 484 .

Ibid at 486 .

(1981), 20 Alta LR (2d) 33 (QB) [World Land].

Ibid at 45 .

Ibid at 50 .

Ibid at 51.

Supra note 2 at paras 13-14 [emphasis in original].

Ibid at para 14 . 
It should be noted that there is no rule of law requiring narrow interpretation of a force majeure clause against the party seeking its protection. ${ }^{45}$ However, as reflected in the examples set out above, courts often do apply a strict construction. The rationale may be one of several. Sometimes the clause is described as an exclusion of liability clause, which is to be interpreted strictly against the party seeking to avoid liability. ${ }^{46}$ Another reason may be a blurring of the line between frustration and force majeure, with the requirement of impossibility of performance being applied to a force majeure clause regardless of the wording of the clause. ${ }^{47}$ In any event, this strict or narrow construction reflects a fundamental reluctance to relieve parties of their contractual obligations. Whether such rationale is appropriate is a live issue. Parties to commercial agreements often include a force majeure clause as a means of allocating the risk associated with events that would otherwise radically change the nature of one party's obligations. A strict interpretation of a force majeure clause arguably does not give effect to the parties' allocation of risk. We will not attempt to resolve this issue here. Appropriate or not, the fact remains that courts sometimes construe force majeure clauses narrowly and this should be borne in mind when one is negotiating and drafting a force majeure clause.

\section{FORESEEABILITY AND CONTROL}

Most modern force majeure clauses include a requirement that in order for an event to qualify as force majeure it must have been unforeseeable, outside the control of the parties, not caused by the parties, or other similar language. ${ }^{48}$

Even where there is no such language in the clause, the courts have demonstrated a willingness to read it in. In Atlantic Paper, the clause (reproduced above) made no reference to foreseeability or control. However, the Court made the following general statement about force majeure clauses:

An act of God clause or force majeure clause, and it is within such a clause that the words "non-availability of markets" are found, generally operates to discharge a contracting party when a supervening, sometimes supernatural, event, beyond control of either party, makes performance impossible. The common thread is that of the unexpected, something beyond reasonable human foresight and skill. ${ }^{49}$

It is arguable that the Court's thinking in this regard was influenced by the common law of frustration, where the frustrating event would usually have to be unforeseen or outside the control of either party. ${ }^{50}$

Treitel, supra note 9 at 478.

See e.g. Fishery Products International Ltd v Midland Transport Ltd (1992), 100 Nfld \& PEIR 222 at para 1.

$47 \quad$ See e.g. Atcor, supra note 2 at para 11.

48 The clause, however, does not have to include such wording. See e.g. Scanlon $v$ Castlepoint Development Corp (1992), 11 OR (3d) 744 (CA), leave to appeal to SCC refused, 23427 (5 August 1993).

$49 \quad$ Supra note 24 at 583 [emphasis added]. The law in the UK is to the same effect. Treitel states that the UK courts "apply the 'presumption that the expression force majeure is likely to be restricted to supervening events which arise without the fault of either party and for which neither of them has undertaken responsibility.” Treitel, supra note 9 at 480 [footnotes omitted, emphasis in original].

50 The Court may also have had in mind the civil law concept of "force majeure," which is defined in the Civil Code of Québec as "an unforeseeable and irresistible event, including external causes with the same characteristics.” Supra note 14, s 1470. 
This was not a statement without consequence. While the Atlantic Paper decision rejected the argument of force majeure on a number of points, including the interpretation of "availability of markets," it is submitted that what it really turned on was the issue of foreseeability and control. The Court stated:

I do not think St. Anne can rely on a condition which it brought upon itself. A fair reading of the evidence leads one to conclude that the whole St. Anne project for the manufacture of corrugating medium was misconceived. The problems which plagued it proceeded, however, not from non-availability of markets for corrugating medium.... The project, conceived in ephemeral hopes and not the harsh realities of the market place, resulted in a failure for which St. Anne and not changes in the market for corrugating medium during the period April 10, 1970 to June 9, 1971 must be held accountable. ${ }^{51}$

Perhaps as a result of the Supreme Court's statement in Atlantic Paper, there is sometimes confusion between foreseeability and control. Justice Gould of the British Columbia Supreme Court addressed this issue in West Fraser Mills Ltd $v$ Crown Zellerbach Canada Ltd. ${ }^{52}$

The facts in West Fraser were not dissimilar to those in Atlantic Paper. In West Fraser, the defendant Crown Zellerbach Canada Ltd (CZC) contracted with West Fraser Mills Ltd (West Fraser) for the long term purchase of pulp to be used by CZC to make newspaper print. ${ }^{53}$ The contract contained an "Economic Clause" which the Court concluded was a force majeure clause. ${ }^{54}$ The events listed in the clause included "market conditions":

\footnotetext{
If the paper manufacturing facilities at the Buyer's pulp mill should be shut down or curtailed because of fire, breakdown, strike, riot, labour dispute, war, flood, market conditions or any other cause whether or not similar to the foregoing which requires the Buyer to reduce or halt its supply of pulp to its paper manufacturing facilities, then the Buyer may, at its option and without liability under this Agreement during any such period of shutdown, either suspend entirely its purchase of TMP under this Agreement or reduce such purchases to such an extent as the Buyer may elect from time to time. ${ }^{55}$
}

There was little dispute that market conditions did deteriorate significantly after the contract was formed, resulting in CZC's sales of newsprint declining significantly. ${ }^{56} \mathrm{CZC}$ gave notice under the force majeure clause that it was reducing its purchases of pulp from West Fraser. ${ }^{57}$ West Fraser denied that the decline in market conditions was a force majeure event, arguing that the decline was foreseeable at the time of the contract. It called a university professor of business who gave evidence to that effect. ${ }^{58}$

The Court accordingly addressed the question of the appropriate test for whether the market downturn was a "market condition" as contemplated by the force majeure clause. ${ }^{59}$ The Court noted that the parties had listed "market conditions" in their list of force majeure

Atlantic Paper, supra note 24 at 587 [emphasis added].

(1983), 23 BLR 126 (BCSC) [West Fraser].

Ibid at 128 .

Ibid at 136 .

Ibid at 129 [emphasis in original].

Ibid at 139 .

Ibid at 128 .

Ibid at 142-43.

Ibid at $136-137$. 
events. ${ }^{60}$ As such the contingency of a change in market conditions was one that the parties turned their minds to, and was therefore foreseeable. ${ }^{61}$ Although the word "foresight" appears in the test framed by the Court, it is submitted that the ultimate focus was on control:

I think the highest duty that attaches to CZC under the contract, qua its defence that drastic shortage of sales volume at and after March 25, 1982, constitutes justification for suspension of deliveries as at that date, is that the drastic shrinkage in sales must have been, in the words of Dickson J. "an event over which the respondent exercises no control". Another way of expressing the proposition, and again words from the same judgment, the drastic shrinkage in sales must be "beyond reasonable human foresight and skill” to prevent.

The first thing, then, that CZC must prove is (1), that at the time claimed there was a significant reduction in sales volume. If the defendant succeeds in that, it must also prove (2), that it was not caused by lack of reasonable marketing skill on its part, and (3), that it was not something over which CZC could have exercised control such as to prevent it. ${ }^{62}$

In spite of the expert evidence that a reasonably knowledgeable person in the newsprint industry should have anticipated the downturn, the Court concluded that CZC's significant loss of sales was not caused by any failing of CZC in the planning or execution of its business, as was the case in Atlantic Paper, but that the loss of sales was caused by a general market decline over which CZC had no control. As such, CZC's reduction in the purchase of pulp from West Fraser was permitted by the force majeure clause. ${ }^{63}$

It is relatively common for a plea of force majeure to be denied because the force majeure is "self-induced," that is, within the control of the party claiming benefit of the clause. ${ }^{64}$

\section{EVENTS Up AND DOWN THE CHAIN}

There are two scenarios in which events that occur up or down a contractual chain can give rise to a potential claim of force majeure. First, does negligence or some other failure to perform by a supplier or service provider that in turn causes the contracting party to default constitute force majeure? Second, in some cases the events listed in the force majeure clause do not happen directly to one of the contracting parties, but rather, to a party's customer or supplier. What is the result if, for example, in a supply contract with a force majeure clause, a strike occurs at one of the purchasing party's main customers, thus significantly reducing that party's demand for product?

$60 \quad$ Ibid.

$61 \quad$ Ibid at 136-37. The distinction may be one between "foreseeable" and "foreseen."

$62 \quad$ Ibid at 137 [emphasis added].

63 Ibid at 145 .

$64 \quad$ See e.g. Newfoundland (AG) v Churchill Falls (Labrador) Corp (1983), 49 Nfld \& PEIR 181 (TD) at paras 682-87 (entering into two conflicting contracts does not create an event of force majeure); World Land, supra note 39 at para 42 (while the normal time for municipal approval of a development permit may count as force majeure, the delay as a result of not complying with the requirements for the permit application definitely does not); Wal-Mart Canada Corp v Gerard Developments Ltd, 2010 ABCA 149, [2010] AWLD 2475 at para 17 (no force majeure where party could have met deadline to complete road had it applied due diligence in requesting information, obtaining approvals, obtaining professional services, etc.). It is noted that analytically, some cases of "self-induced" force majeure could also be seen as causation cases (something other than a force majeure causes the lack of performance) and sometimes as cases of failing to mitigate. 
Both of these scenarios can be dealt with expressly in the force majeure clause and it is advisable for drafters to consider doing so. The case law on the subject is limited enough that in order to have a reasonable level of certainty, specific drafting is warranted. It is also advisable when dealing with a series or chain of related contracts to have mirror force majeure provisions to the extent possible so as to avoid gaps (that is, situations where "party A" is in default of its obligations to "party B" as a result of a default by "party C," and C is relieved from performance by way of a broad force majeure clause but A does not have the same entitlement under its contract with $\mathrm{B}$ because the force majeure clause is more narrow).

In the case of default or negligence by someone up or down the chain, the general rule, subject of course to the specific wording of the clause in question, is that a default by an independent contractor that impacts performance by the contracting party can be an event of force majeure to excuse that party's performance. ${ }^{65}$ However, there is very little discussion of the issue in the jurisprudence. Of course, if the contracting party is negligent in the way they have handled the third party (for example, not supervising properly or failing to provide information or materials required by the third party to perform), then there will be hurdles to invoking force majeure, particularly in light of many clauses specifically stating that an event cannot be force majeure when caused by the negligence of the invoking party. ${ }^{66}$

With respect to second level force majeure events, that is, events that would qualify as force majeure if they occurred as between the two contracting parties but they occur up or down the chain, the jurisprudence offers mixed results.

In TransCanada Pipelines Ltd v Northern \& Central Gas Corp ${ }^{67}$ TransCanada Pipeline Ltd (TransCanada) agreed to supply gas to Northern \& Central Gas Corp (Northern). The contract included a force majeure clause with events listed, including strikes. ${ }^{68}$ Several of Northern's customers had been hit by strikes, which significantly reduced Northern's demand for gas. ${ }^{69}$ The Ontario Court of Appeal defined the issue: "In this case, does the term include a 'strike' anywhere which prevents Northern from selling gas to its customers or is it limited to 'strikes' at Northern?”70

The Court noted that the force majeure clause contained explicit protection for TransCanada for events relating to its suppliers and concluded that if the parties had intended to similarly protect Northern from events affecting its buyers, then the contract would have explicitly done so. ${ }^{71}$

The Court was clearly concerned about the scope of the clause, and the possibility that the clause could be used for events far removed from those that would have a direct impact on one of the parties. ${ }^{72}$ Absent explicit language demonstrating an intention for such risks to be

Treitel, supra note 9 at 480-81, citing Coastal (Bermuda) Petroleum Ltd v VTT Vulcan Petroleum SA (The Marine Star (No 2)), [1996] 2 Lloyd's Rep 383.

For instance, see definition of "Force Majeure" in CAPL Operating Procedure, supra note 23 at 6.

(1983), 41 OR (2d) 447 (CA) [TransCanada].

Ibid at 448 .

Ibid at 449 .

Ibid at 451 .

Ibid at 453.

Ibid at 454 . 
captured by the force majeure clause, the Court declined to read the clause in such a broad manner. ${ }^{73}$ The Court found that Northern was effectively seeking business interruption insurance from TransCanada in circumstances where only Northern had control over Northern's business, including the terms and conditions of its contracts with third parties. ${ }^{74}$

This concern about expanding the force majeure clause to events or risks far removed from the parties themselves also resulted in a narrow reading of the basket clause:

This leads me to the view that the third and fourth subclauses of the section which refer to acts, omissions or similar causes not within the control of Northern, should be interpreted as being restricted to those force majeure events which occur on Northern's system. For example, the "acts or omissions of parties not controlled by the party" is referable to acts of those hired by a party to the contract to rectify a force majeure event on their system. ${ }^{75}$

The British Columbia Court of Appeal came to a different conclusion in Tenneco Canada Inc v British Columbia Hydro and Power Authority. ${ }^{76}$ There, a strike up the chain was found to be a force majeure event. The Court distinguished the decision in TransCanada on a number of grounds, including the one-sided clause relating to third party events in TransCanada, and held:

Perhaps most importantly in my view, there is an answer in this case to the rhetorical questions posed by Cory J.A., regarding where to draw the line between strikes besetting customers and those besetting suppliers of customers, suppliers of suppliers of customers, etc. The line surely becomes clear where the plant of one of the contracting parties has had to shut down due to a strike and has virtually no need for electricity. The effect on the customer is exactly the same as if its own workforce had been on strike. ${ }^{77}$

Atcor also dealt with a third party event of sorts. Atcor's ability to supply gas to Continental was compromised by compressor breakdowns, pipeline repairs, and other issues on the Nova pipeline carrying Atcor's gas. ${ }^{78}$ The force majeure clause included "breakages of or accidents to plant, machinery or lines of pipe ... pipeline connections, pipeline repairs ... not within the control of the party claiming suspension."79 Based on that wording, it was common ground that the pipeline issues created an event of force majeure. ${ }^{80}$ Atcor's plea of force majeure was denied on other grounds.

It is becoming more and more common for parties to address third party occurrences in their force majeure clauses. ${ }^{81}$

Ibid at 454 .

Ibid.

Ibid at 455 [emphasis in original].

(1999), 126 BCAC 9 [Tenneco].

Ibid at para 44. Although it was obiter, the Court also found that even if they had given a more narrow interpretation to the term "strike" as specifically listed in the force majeure clause, they would have considered the third party strike a force majeure event under the basket clause (ibid at para 46).

Supra note 2 at para 2.

Ibid at para 3.

Ibid at para 4.

For example, the AIPN Model Agreement, supra note 21, art 1.1: "Force Majeure Event" includes an option: "failure of [ ] [insert specified third party] to [ [insert specified actions] for reasons that would constitute a Force Majeure Event as defined in this Agreement if the [ [insert specified third party] were a Party to this Agreement.” 


\section{POINTS OF INTEREST ON SOME PARTICUlAR TRIGGERING EVENTS}

Two commonly referenced events of force majeure that may be of interest to energy practitioners are strikes and lost markets.

\section{a. $\quad$ Strikes}

Traditionally, strikes and other work interruptions were not of much interest to the energy industry in Canada because it has largely been non-unionized. However, with the growth of large-scale construction projects such as oil sands development, labour issues are becoming more prevalent.

Along with the issue of "third party strikes" discussed above, a common issue is the breadth of the force majeure definition of "strikes." Usually, there is no dispute in circumstances where the party claiming force majeure has a unionized work force that goes on strike. But what about other types of work disruptions?

MacMillan Bloedel Ltd v British Columbia (Hydro and Power Authority) involved a longterm electricity supply contract. ${ }^{82}$ The list of events in the force majeure clause included "a strike occurring at the premises” of MacMillan Bloedel Ltd (MacMillan Bloedel). ${ }^{83}$ MacMillan Bloedel's plant operations were shut down because of an employee work stoppage as part of a province-wide protest against provincial labour legislation. ${ }^{84}$ MacMillan Bloedel sought relief from payment of its monthly hydro demand charges, one of its remedies for force majeure. ${ }^{85}$ The issue was whether the work stoppage was a "strike" within the meaning of the force majeure clause. ${ }^{86}$

The British Columbia Hydro and Paper Authority (BC Hydro) argued that the work stoppage was not a strike because it was not undertaken for the purpose of compelling an employer to agree to certain terms and conditions of employment, and therefore did not meet the definition of strike under the Industrial Relations Act. ${ }^{87}$ The work stoppage was part of a political protest. The British Columbia Court of Appeal rejected BC Hydro's argument, finding that the definition in the Act was limited to proceedings in the labour relations context. ${ }^{88}$ In a commercial agreement for the supply of electricity, the natural and ordinary meaning of the word "strike" governed. ${ }^{89}$ The Court found that the work stoppage met the ordinary meaning of the word "strike" and an event of force majeure had occurred. ${ }^{90}$

In contrast, in Fishery Products International Ltd v Midland Transport Ltd ${ }^{91}$ there was no "strike" found under a force majeure clause contained in a contract of carriage when the carrier's trucks were delayed by a road block and protest by independent truckers attempting

(1992), 98 DLR (4th) 492 (BCCA).

Ibid at 494.

Ibid.

Ibid 494-95.

Ibid 493.

Ibid at 499, 501. SBC 1973, с 122.

Ibid at 501.

Ibid.

Ibid 502-503.

(1994), 119 Nfld \& PEIR 153 [Fishery Products]. 
to raise awareness of perceived problems in the trucking industry. The Court focused on the fact that the protest had nothing to do with an employer/employee relationship. ${ }^{92}$

\section{b. Existence/Loss of Market}

As discussed above, the decisions in Atlantic Paper and West Fraser involved alleged changes in market conditions giving rise to claims of force majeure. In both cases the Court emphasized that for force majeure to apply, the party claiming force majeure had to show that market conditions themselves had changed, rather than the party having structured its business in a manner that made it uncompetitive. The courts in the two cases came to different results based on their respective facts and the clause at play.

American courts have also had an opportunity to consider "loss of market" scenarios. Valero Transmission Co v Mitchell Energy Corp ${ }^{93}$ arose from a gas purchase contract. Valero Transmission Co (Valero) agreed to purchase gas produced from Mitchell Energy Corp (Mitchell) for 20 years at set prices. ${ }^{94}$ The contract contained a force majeure clause excusing failure of performance on Valero's part "due to causes beyond its reasonable control."95 When gas prices fell, Valero no longer complied with the minimum purchase and take requirements of the contract. ${ }^{96}$ Mitchell sought a temporary injunction forcing Valero to take and pay for gas because Mitchell's wells were being drained by offsetting producers and it was in danger of losing certain leases for non-production. ${ }^{97}$ Valero argued force majeure, as the regulatory regime left it with minimal control over the price at which it could sell gas and neither party could control the downstream market demand for gas. ${ }^{98}$ The Court rejected the argument:

\footnotetext{
An economic downturn in the market for a product is not such an unforeseeable occurrence that would justify application of the force majeure provision, and a contractual obligation cannot be avoided simply because performance has become more economically burdensome than a party anticipated.... Indeed, the uncertainty of future market prices is often the motivation for entering into a long-term contract.... [A] sudden or significant change in price...is not sufficient to constitute an extraordinary, unforeseeable event that would excuse performance under the force majeure clause. ${ }^{99}$
}

There was a different result in Kodiak 1981 Drilling Partnership v Delhi Gas Pipeline $\operatorname{Corp}^{100}$ due to the inclusion of express wording regarding a change of market. The gas purchase agreement contained a force majeure clause that included an Enumerated Risk for "partial or entire failure to gas supply or market."101 The trial court found that the market

\footnotetext{
Ibid at para 22.

743 SW (2d) 658 (Tex App 1987).

Ibid at 660 .

Ibid at 663 .

Ibid at 660 .

Ibid at 659-60.

Ibid at 663 .

Ibid at 663-64 [citations omitted].

736 SW (2d) 715 (Tex App 1987).

Ibid at 716 .
} 
failed “unforeseeably and uncontrollably," thus excusing the purchaser's obligation under the force majeure provision. ${ }^{102}$ The Court of Appeals of Texas affirmed the decision. ${ }^{103}$

\section{B. IMPACT AND CAUSATION}

It is not enough for a party invoking force majeure to establish that the event in question is an "event" within the contractual definition of force majeure. That party must show that the force majeure event impacted that party’s ability to perform its contractual obligations.

A number of issues can arise relating to the question of impact. A common issue is the extent of the impact on the party. Must the force majeure event render performance of the contractual obligations impossible or is some lesser impact sufficient?

Another issue is causation. Was the force majeure event and its impact the cause of the failure to perform or was there a separate cause? This issue often involves consideration of whether the contract contemplated that there were other means for the invoking party to perform its obligations that would not involve the force majeure event. For example, a disruption in a supplier's supply chain might be found to be a force majeure event, but what if the supplier had other supply chains or means of delivering that were unaffected? In such cases, a court may find that there is no relief from that party's obligation, even though a force majeure event occurred and impacted that party’s ability to perform.

\section{IMPACT}

In determining what impact is required from a force majeure event for a party to be entitled to relief, the starting point is the language of the contract. As noted in Atcor, a force majeure clause should address the required threshold impact. ${ }^{104}$ While many clauses use "unable to perform" as the threshold, there are other options including interference with performance, hindering performance, commercially impracticable to perform, delayed performance, or inadequate performance. ${ }^{105}$

An example of an event lacking enough impact to trigger relief is found in Re Tom Jones \& Sons Ltd $v R .^{106}$ The contract was for the construction of a building. The force majeure clause contained causation language providing that the events must have "prevented or delayed ... construction or completion of the building."

After entering the contract, the contractor determined that it was uneconomical because the only financing available was at commercially unacceptable rates. The Court found that

\footnotetext{
$102 \quad$ Ibid at 717.

103 Ibid at 724. Note that while the trial Court used the language "unforeseeably and uncontrollably," the Court of Appeals questioned whether there was any requirement for unforeseeability.

$104 \quad$ Supra note 2 at para 12.

See e.g. Hanna (MA) Co v Sydney Steel Corp (1995), 136 NSR (2d) 241 at para 27 (SC) [MA Hanna] for an example of a low impact threshold: "If, by reason of any impediment of whatsoever nature, including but not by way of limitation, action of military, naval or civil authorities.” (1981), 31 OR (2d) 649.

Ibid at 653 .
} 
while the increase in interest rates was clearly beyond control of the party, it did not prevent construction of the building. ${ }^{108}$

Drafters should be aware that, if the force majeure clause does not contain clear language setting out the required impact of the force majeure event, the court may have preconceived notions about force majeure clauses generally that will impact its interpretation. For example, in Atlantic Paper, the purchaser represented and warranted that it would purchase a defined minimum amount of waste paper in a given year, "unless as a result of" certain force majeure events. ${ }^{109}$ In the Court's general statement about force majeure clauses, it assumed an impossibility standard:

An act of God clause or force majeure clause, and it is within such a clause that the words "non-availability of markets" are found, generally operates to discharge a contracting party when a supervening, sometimes supernatural, event, beyond control of either party, makes performance impossible. ${ }^{110}$

There was nothing on the face of the clause itself that required that the supervening event rendered performance impossible, as opposed to a lesser standard such as impracticability. Recall that the common law doctrine of frustration includes notions of "impossibility" of performance. It is arguable that this common law concept influenced the Court's interpretation of the otherwise silent force majeure clause.

In Atcor, the Court was similarly faced with a force majeure clause that did not precisely define the impact required from the force majeure event for a party to obtain relief from its obligation. The clause on its face merely required a "failure" to perform a covenant or obligation that was "occasioned by, or in consequence of" a force majeure event. ${ }^{111}$

The Court, without particular reference to the clause before it, did not require impossibility, but rather that the force majeure event rendered performance "commercially unfeasible."112 It found that "preventing” performance was too strict of a standard but that "hindering” performance was too lenient, in that it would allow a party to escape obligations based on inconvenience alone. ${ }^{113}$ The Court stated:

A supplier need not show that the event made it impossible to carry out the contract, but it must show that the event created, in commercial terms, a real and substantial problem, one that makes performance commercially unfeasible. ${ }^{114}$

The decisions in Atlantic Paper and Atcor demonstrate that in the absence of clear language about the impact required from the force majeure event, the courts have found a range of thresholds. Clear language in the force majeure clause about the impact required to invoke force majeure should help avoid uncertainty.

$\begin{array}{ll}108 & \text { Ibid at } 654 . \\ 109 & \text { Supra note } 24 \text { at } 582 . \\ 110 & \text { Ibid at } 583 \text { [emphasis added]. } \\ 111 & \text { Supra note } 2 \text { at para } 3 . \\ 112 & \text { Ibid at para } 11 . \\ 113 & \text { Ibid at para } 17 . \\ 114 & \text { Ibid at para } 11 .\end{array}$




\section{CAUSATION}

Most modern force majeure clauses require that the event of force majeure cause a requisite level of interference with performance. For example, "results in the party being unable to perform" or "if a party is prevented by force majeure." Clauses with weaker language such as "in case of an event of force majeure" may be interpreted as not requiring a causal connection between the event of force majeure and non-performance. ${ }^{115}$

The issue that usually arises is whether the impact of the force majeure event was the cause of the failure to perform. Sometimes this analysis is simply another way of looking at the issue of impact. For example, if a court concludes the required impact is "impossibility," but the force majeure event only rendered performance difficult, not impossible, the court will conclude that the force majeure event did not cause the failure to perform.

There is, however, another aspect to causation relating to the question of whether the party claiming force majeure explored and pursued all available options for performing its obligation. Typically, this issue arises when the party can demonstrate that a force majeure event has impeded it from one means of performing its obligations, but the other party alleges there were alternate methods of performing that were not pursued.

An example of this is found in Atcor. Atcor agreed to supply Continental with gas via a particular pipeline owned by a stranger to the contract. ${ }^{116}$ The list of events in the force majeure clause included "breakages of or accidents to ... lines of pipe ... pipeline repairs and reconditioning." 117 Events occurred on the pipeline that reduced the supply available to Atcor. ${ }^{118}$

At trial, the judge emphasized the fact that the clause spoke about a failure to perform occasioned by or in consequence of a force majeure event, as opposed to language such as "unable" or "impossible" to perform. ${ }^{119}$ The clause read as follows:

Subject to the other provisions of this paragraph, if either party to this Agreement fails to observe or perform any of the covenants or obligations herein imposed upon it and such failure shall have been occasioned by, or in consequence of force majeure, as hereinafter defined, such failure shall be deemed not to be a breach of such covenants or obligations. ${ }^{120}$

The trial judge accepted Atcor's argument that it had reduced deliveries of gas to Continental due to the problems on the pipeline. The "failure to perform" was "occasioned by" or "in consequence of" force majeure as defined in the contract. ${ }^{121}$

Based in large part on his finding that the failure to perform need only have been "occasioned by" the force majeure event, the trial judge found that it did not matter whether

See discussion in Treitel, supra note 9 at 478-79.

Supra note 2 at para 2.

Ibid at para 3 .

Ibid at para 2 .

Ibid at para 6 .

Ibid at para 3.

Ibid at para 6 . 
Atcor was able to perform the contract by other means, such as purchasing replacement gas in the spot market. It was sufficient for Atcor to show that it had failed to provide the gas and that the reason was the reduced supply available from the pipeline. ${ }^{122}$

The trial judge also addressed a so-called "exception” clause in the contract, which provided that a party was not entitled to the benefit of the force majeure clause to the extent that the failure to perform was caused by the invoking party "having failed to remedy the condition, and to resume” performance of its obligations. ${ }^{123}$ The trial judge found that the clause was intended to address circumstances where the invoking party failed to remedy the event of force majeure, for example, having failed to extinguish a fire or fix a pipe within its control. The exception clause did not require the invoking party to remedy the effects of the force majeure, being the shortage of gas from the pipeline. ${ }^{124}$

The Court of Appeal overturned the judgment, emphasizing the importance of causation in force majeure clauses, and expressed concern that the relatively weak causation requirement found by the trial judge would allow parties to escape from obligations almost at will. The Court stressed the importance of a significant causation threshold: "In my view, the contractual requirement for a causal tie between event and non-performance evidences the intention of the parties that the relationship between the two must be substantial, not incidental." 125

The Court of Appeal went on to reject the trial judge's emphasis on the "failure to perform" language, finding that such wording did not eliminate the inquiry into the duty of the supplier to mitigate or avoid the consequences of the event, if it was "commercially reasonable and feasible" to do so. ${ }^{126}$ In other words, could Atcor have performed its obligations in another manner, such as by purchasing gas in the spot market? Because the trial judge did not address this factual issue, the Court of Appeal ordered a new trial. ${ }^{127}$

It should be noted that the Atcor Court of Appeal judgment also deals with the issues of allocation and purchase of replacement gas in the context of the duty to mitigate. ${ }^{128}$ There is not a bright line between the causation analysis and the duty to mitigate analysis. Some of the Court's reasoning that more specifically relates to mitigation is further discussed below.

\section{a. Allocation Issue}

The issue of allocation that arose in Atcor is not unique. Questions about how a supplier to multiple buyers should distribute a diminished supply when faced with a force majeure event arise from time to time. Must the supplier allocate the supply proportionately amongst all of its buyers, or can it chose to claim force majeure under a single contract, deliver nothing to that counter-party, and continue to meet its supply obligations to other buyers?

$\begin{array}{ll}122 & \text { Ibid at para 7. } \\ 123 & \text { Ibid at para 8. } \\ 124 & \text { Ibid. } \\ 125 & \text { Ibid at para 11. } \\ 126 & \text { Ibid at para 14. } \\ 127 & \text { Ibid at paras 35, 43. } \\ 128 & \text { Ibid at paras 26-36. }\end{array}$


The allocation issue is often referred to as a causation issue, with the buyer, who has been denied its supply, arguing that the force majeure event did not cause its loss of supply; rather, it was the supplier's decision to force a single buyer to bear the entire burden of the shortage. Sometimes the issue is described as one of mitigation involving an assertion by the buyer that the supplier has an obligation to mitigate the effect of the force majeure event by proportionately allocating supply.

In Atcor, the Court treated the issue as one of causation. In doing so, the Court refused to accept that in every case the supplier has a positive duty to ration the available product amongst all its customers. ${ }^{129}$ Instead, the supplier merely had to show it acted reasonably in its distribution of available supply. ${ }^{130}$ If it did so, then the force majeure was the cause of the failure to supply, not the supplier's allocation. The Court adopted the reasoning of the UK Court of Appeal in Bremer Handelsgesellschaft mbH v Continental Grain Co: $:^{131}$

[T] ]e question resolves itself into a question of causation; in my judgment, at least in a case in which a seller can (as in the present case) claim the protection of a clause which protects him where fulfillment is hindered by the excepted peril, subsequent delivery of part of his available stock to other customers will not be regarded as an independent cause of shortage, provided that in making such delivery the seller acted reasonably in all the circumstances of the case. This is because, in the absence of any contractual term to the contrary, the buyer under a contract containing such a clause must contemplate that the seller has other customers besides himself, and must also contemplate that the seller will take reasonable steps to fulfill the needs of other customers; and reasonable action so taken by the seller should not in these circumstances be regarded as a cause or shortage independent of the expected peril. ${ }^{132}$

The above passage emphasizes that as long as the supplier acted reasonably in deciding to fulfill some of its supply obligations while claiming force majeure in respect of others, that decision will not be considered the "cause" of failure to supply so as to deprive the supplier of the remedy of force majeure. A buyer will often know that a supplier has numerous customers and in agreeing to a force majeure clause is presumed to know that, faced with a force majeure event, the supplier will have to decide how to distribute supply amongst multiple buyers. ${ }^{133}$

The Court in Atcor went on to find that the burden of proving that the supplier acted reasonably in claiming force majeure under one contract while continuing to supply others was with the supplier. ${ }^{134}$ Again, because the trial judge did not address this factual issue, a new trial was required.

The issue of the duty to allocate scarce supply can be dealt with explicitly in the force majeure clause. Many parties contract specifically for a certain allocation of supply upon an event of force majeure. ${ }^{135}$

\footnotetext{
$129 \quad$ Ibid at para 18.

$130 \quad$ Ibid at para 21

131 (1982), [1983] 1 Lloyd's LR 269 (CA) [Bremer].

$132 \quad$ Supra note 2 at para 19, citing Bremer, ibid at 292.

133 Treitel, supra note 9 at 540 makes the same point in the context of frustration.

$134 \quad$ Supra note 2 at para 21.

$135 \quad$ See e.g. AIPN Model Agreement, supra note 21, art 19.6.
} 


\section{RESUlT AND EXPECTED BEHAVIOUR}

The third element of a good force majeure clause addresses the consequences of the force majeure event and the related inability or failure to perform. Considerations relating to this third element include: notice, rights and obligations of the invoking party, including mitigation, and rights and obligations of the other party. These points are addressed below along with some other interesting legal issues that arise when force majeure is invoked.

\section{NOTICE}

The law is relatively settled that a party giving notice of force majeure must strictly comply with the terms of the notice provision. It is treated as a condition precedent and, if not fulfilled, the party cannot rely on the force majeure clause. ${ }^{136}$

Because of this, drafters should try to ensure that the notice provision will be practically workable in the contemplated circumstances. It is also advisable, to the extent possible, to make sure that clients understand the importance of the notice provision such that they seek legal advice and can issue notices before it is too late.

While making the notice provision reasonably workable for the invoking party, drafters will want to consider what protection is required for the receiving party. The requirements will depend on the particular contemplated events and their likely impact on the respective businesses of the parties. Along with timely notice, however that may be defined, it is wise to consider whether notice should be accompanied with a reasonable statement of particulars of the force majeure event - if for no other reason than to allow the receiving party a reasonable opportunity to challenge the application of force majeure on a timely basis. Also, query whether in the circumstances it would be appropriate for the party invoking force majeure to be required to provide periodic updates on the status of the force majeure event, its expected duration, and any efforts to address it. ${ }^{137}$

\section{RightS AND OBLIGATIONS OF THE PARTIES}

Unlike frustration under common law, parties to a contract are free to agree to the legal effect of the force majeure event. If a contract is frustrated at common law, the result is that both parties are discharged from their obligations.

Various legal results are seen in the force majeure case law and in typical clauses. These can range from mere suspension of obligations during the force majeure event to termination of the agreement itself. In some cases, performance is only excused to the extent the party is unable to perform; in other words, partial performance is required if possible. In others, partial performance is not desirable. A further advantage of addressing these issues by contract is that the applicable remedy may be different depending on the particular force majeure event. For example, some events might merely suspend obligations or extend the requirement that the party receiving the force majeure notice have an entitlement to access the facilities affected by force majeure. 
time to perform, while others would result in termination of the contract itself. In any event, it is important to consider the desired legal results when drafting the force majeure clause.

An illustration of the importance of drafting an appropriate legal remedy in the force majeure clause is Boligomsetning As v Terpstra Management Ltd. ${ }^{138}$ In Terpstra, adverse weather prevented the supplier from delivering pulpwood by the date required by the contract. ${ }^{139}$ The supplier invoked force majeure and proposed to simply delay delivery. ${ }^{140}$ The force majeure clause, however, read:

\begin{abstract}
Should fulfillment of this contract or any part of same be prevented or hindered by reason of Force Majeure such as Act of God, war, drought, immobilization, flood, strike, lock-out, storm, ice, fire, obstruction of navigation, Governmental restrictions or other causes beyond the control of the parties specifically enumerated above, they shall not be held responsible for any damages resulting therefrom to other party, providing the party not able to fulfill this contract gives notice as soon as possible to the other party about his being prevented or hindering from filling this contract, or any part of it, and prove same. ${ }^{141}$
\end{abstract}

The Court found that the force majeure clause did not permit the party claiming force majeure to deliver late; it merely relieved the party responsible from liability for consequent damages. $^{142}$

The foregoing discussion is focused on the legal effect of force majeure on the invoking party. Drafters should also consider the legal position of the party receiving a notice of force majeure. For example, are that party's obligations also suspended, including any obligation to pay? Is that party entitled, after some period of time, to elect to terminate the agreement rather than continue in a state of force majeure?

\title{
3. Mitigation
}

One of the issues that frequently arises in the jurisprudence is the duty of the party invoking force majeure to mitigate. Many clauses include an express obligation to mitigate or overcome the event of force majeure to the extent possible. ${ }^{143}$

As noted in Part III.B.2, the mitigation issue can be linked to causation. In Atcor, one issue was whether Atcor had a duty to mitigate the effect of the force majeure event by purchasing gas to fulfill its obligation to Continental. ${ }^{144}$ The Court of Appeal noted that this issue might be considered an issue of mitigation or causation:

The question of re-supply from new sources very much requires one to ask what is the real purpose of the force majeure clause. The key here is not so much causation as a duty to mitigate, although I suppose one

(1989), 75 Nfld \& PEIR 239 (SCTD) [Terpstra].

Ibid at para 5.

Ibid at para 10

Ibid at para 12 [emphasis added].

Ibid at para 13.

Some clauses provide very detailed mitigation options and examples of steps that need not be taken. In the AIPN Model Agreement, for example, there is a specific option that addresses the issue in Atcor: "A Claiming Party shall not be required to buy Gas from, or sell Gas to, a third party (supra note 21, art 19.4.4).

Supra note 2 at para 27. 
may contend that lack of mitigation is a sort of cause of non-delivery. For example, Donaldson, J., in Wildhandel (1975), at p. 242 said that the simple words "cause beyond their control” import a duty to mitigate because a cause that could be alleviated was not a cause beyond control. ${ }^{145}$

The Court of Appeal went on to treat the duty to mitigate broadly. The trial judge had found that the question was whether Atcor could overcome the force majeure event itself, namely problems on the pipeline owned by a third party, which obviously it could not. The Court of Appeal rejected this narrow test for mitigation and held that the force majeure clause should be read as requiring the party to mitigate the effect of the force majeure event. ${ }^{146}$

The Court thus found that Atcor had a duty to mitigate the effect of the pipeline disruption by acquiring replacement gas in the spot market, if it were reasonable to do so in the circumstances. ${ }^{147}$ No guidance was provided on what would be "reasonable," and the issue of whether Atcor had a duty to purchase replacement gas was remitted back to trial. ${ }^{148}$

It is interesting that although the Court in Atcor accepted that a supplier's reasonable decision to favour one buyer over another in the event of a shortage of supply caused by a force majeure event would not deprive the supplier of its force majeure remedy, it accepted that the supplier might nevertheless have a duty to buy replacement gas on the spot market. In concluding that a reasonable decision on distributing supply would not deprive the supplier of the force majeure remedy, the Court reasoned that a buyer who agrees to a force majeure clause should reasonably expect that its supplier might make that very decision, and thus be faced with no supply. Presumably the buyer was prepared to accept that risk in agreeing to the force majeure clause. It seems odd for the Court in Atcor to have contemplated that in those same circumstances the supplier might be required to bear the cost of that risk, by purchasing replacement gas for the buyer at a higher price in the spot market.

This same issue has been dealt with in the US with conflicting case law. In Tejas Power Corp v Amerada Hess $\operatorname{Corp}^{149}$ a number of Amerada Hess Corp's (Amerada) wells froze, which limited its upstream supply. ${ }^{150}$ This event was contemplated as a triggering event and was enumerated under the force majeure clause. ${ }^{151}$ Amerada curtailed its supply of natural gas to some, but not all, of its customers and selectively chose those to whom it would make deliveries. ${ }^{152}$ Tejas Power Corp (Tejas) argued that the availability of gas on the spot market would have allowed Amerada with "due diligence to overcome" the effects of the force majeure event as required by the contract. ${ }^{153}$ Tejas's position was that a duty existed to mitigate the effects of force majeure as well as the event itself. The Court of Appeals of Texas rejected this argument, noting that to accept the argument would be to "rewrite a contract or interpret it in a manner the parties never intended." "

Ibid at para 27, citing Wildhandel NVv Tucker \& Cross, [1975] 2 Lloyd's LR 240 (Comm Ct) at $242 .$. Ibid at para 29.

Ibid at para 30 .

Ibid at paras 41-43.

1999 Tex App LEXIS 6014 at 3.

Ibid at 3.

Ibid at 8 .

Ibid at 3-4.

Ibid at 6 .

Ibid at 9 . 
Operating Limited Partnership v Holt,${ }^{155}$ where the Court rejected the argument that the nonperforming party had to use due diligence to overcome the effects of force majeure even if the contract terms did not impose such an obligation. ${ }^{156}$

The issue of mitigation by a supplier, in the context of finding alternate means to supply, also arose in AMCI Export Corp v Nova Scotia Power Inc. ${ }^{157}$ An agreement for the supply of coal required AMCI Export Corp (AMCI) to deliver "South American coal," without reference to a specific mining region. ${ }^{158}$

AMCI failed to deliver coal to Nova Scotia Power, invoking force majeure on the basis that it was impossible to deliver coal due to a rock slide making the main road inaccessible in the region from which AMCI intended to source its coal. ${ }^{159}$ The Nova Scotia Court of Appeal rejected the defence of force majeure, finding that AMCI had not demonstrated that the rockslide in one area of South America prevented it from buying coal from other regions. ${ }^{160}$

The decisions in Atcor and AMCI raise an important drafting point relating to the intended source of supply. If a supplier wants to be able to limit performance to a designated source, and not be forced to source supply from alternate sources if force majeure makes supply from the designated source impossible, this should be set out specifically in the contract.

A good example of reasonable mitigation in the energy context is $H \& R$ Drilling Inc $v$ Aquilo Energy Inc. ${ }^{161} \mathrm{H} \& \mathrm{R}$ Drilling (H\&R) entered into a "Standard Daywork Contract" with Aquilo Energy (Aquilo) in respect of H\&R's “rig \#2."162 Under the contract, Aquilo contracted to use the rig for 125 days per year for two years. ${ }^{163}$ A fire damaged both H\&R's premises and the rig at a time when construction of the rig was 85 to 95 percent complete. ${ }^{164}$

The estimated completion date under the contract was 15 July 1997; as a result of the fire the rig was not ready until early September $1997 .{ }^{165}$ Aquilo did not use the rig as much as expected and refused to pay for the time it did not use the rig. ${ }^{166}$ It argued H\&R had not met its obligation to use best efforts to have the rig ready by 15 July $1997 .{ }^{167}$

The Court held that the fire was an event covered by the force majeure clause in the contract. ${ }^{168}$ Under the force majeure clause, neither party was required to perform its obligations when its performance was "hindered or prevented" by events of force majeure,

984 SW (2d) 277 (Tex App 1998).

Ibid at 292. Note that in Gulf Oil Corporation v Federal Energy Regulatory Commission, 706 F (2d) 444 (Sup Ct App Div 1983), the Third Circuit Court of Appeals suggested that there was a duty to use due diligence to overcome the effects of force majeure. 2008 NSCA 2, 265 NSR (2d) 351 [AMCI].

Ibid at para 3.

Ibid at para 8 .

Ibid at paras 23-24.

(2000), 265 AR 141 (QB) [H\&R Drilling].

Ibid at para 2.

Ibid at para 3.

Ibid at para 15.

Ibid at para 7.

Ibid at para 12.

Ibid at para 16.

Ibid at para 23. 
including fires. ${ }^{169}$ Performance was to resume “as soon as reasonably possible.” ${ }^{170}$ The Court found that H\&R had in fact resumed construction of the rig as soon as reasonably possible after the fire. ${ }^{171}$

$H \& R$ is an example of both reasonable mitigation and the supplier's mitigation being limited to a single intended source of supply. The contract at issue was for supply of a specific rig, H\&R's “rig \#2.” As such, there was no suggestion that as a result of the fire $H \& R$ was required to source a replacement rig for Aquilo.

Another case that arguably involves a failure to mitigate, and that may be of interest to energy lawyers is Prairie Well Servicing Ltd $v$ Tundra Oil \& Gas Ltd. ${ }^{172}$ Prairie Well Servicing Ltd (Prairie Well) contracted to supply service rigs to Tundra Oil \& Gas Ltd (Tundra) ${ }^{173}$ During the course of the contract, several of Prairie Well's employees demanded increases in their wages and benefits. ${ }^{174}$ Prairie Well refused the demands and the employees walked off the job. ${ }^{175}$ Several days later, Prairie Well sold its assets and went out of business. ${ }^{176}$ Prairie Well sued for unpaid accounts and Tundra counterclaimed for damages. In response to the counterclaim, Prairie Well invoked the force majeure clause in the contract and argued that the strike was a force majeure event that relieved it of liability to Tundra. ${ }^{177}$

The Court concluded that while Prairie Well's employees had indeed gone on "strike" and, as such, an event of force majeure had occurred under the contract, ${ }^{178}$ Prairie Well's subsequent decision to sell its assets and go out of business was an abandonment of the contract. ${ }^{179}$ While the force majeure event excused performance for a few days, once Prairie Well sold its assets, performance was not hindered or prevented by the force majeure event but by Prairie Well's abandonment of the contract.

\section{EFFECT OF Force MAJEURe ClaUse ON THE APPLICATION OF THE DOCTRINE OF FRUSTRATION}

Because force majeure clauses developed at least in part to overcome the narrow scope of frustration under the common law, one might assume that the inclusion of a force majeure clause in a contract would, practically speaking, displace the common law doctrine of frustration. That is not necessarily the case.

In the typical scenario, the interplay between frustration and the force majeure clause illustrates one of the main reasons for having a force majeure clause; namely, contracting to include events of force majeure that would not be frustrating events. An example of this was seen in MA Hanna Co, Sydney Steel Corp (Sysco) was a buyer of iron ore pellets under a

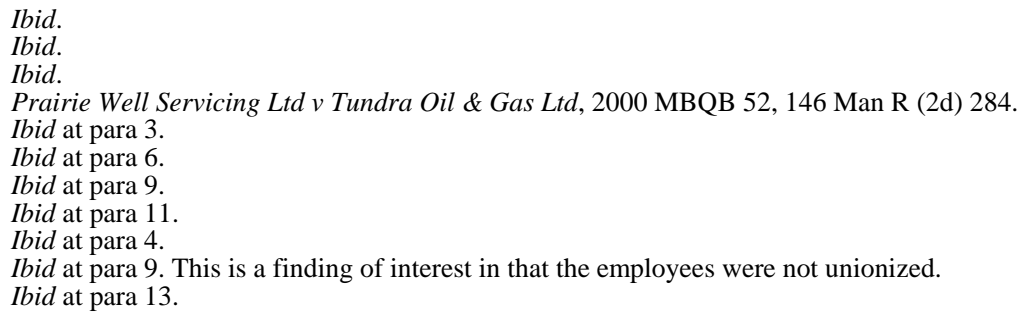


long-term supply contract with Hanna (MA) Company. ${ }^{180}$ Sysco argued that the crash in the steel market and Sysco's plan in response to the crash to change its steelmaking technology so as to reduce its demand for pellets was a force majeure event. ${ }^{181}$ Sysco also argued frustration.

The Court rejected the frustration argument, finding that while performance of the contract by Sysco had become commercially unprofitable, the changed market did not render performance of the contract physically or legally impossible. As such, frustration was not available. ${ }^{182}$ The Court, however, went on to read the force majeure clause, which was drafted very generally and broadly, as applying to the changed circumstances of the steel industry. ${ }^{183}$

Interestingly, however, there are also cases where the court rejects force majeure but finds frustration. British Columbia (Minister of Crown Lands) v Cressey Development Corp ${ }^{184}$ is an example of such a case, although the result is unusual and arguably incorrect. Cressey Development Corp (Cressey) entered into an agreement to purchase lands from the Province of British Columbia, with the intent of subdividing the lands and selling serviced lots. ${ }^{185}$ Cressey had proposed that the agreement be made contingent on rezoning, but British Columbia rejected the proposal and the agreement was signed absent a condition about rezoning. Cressey paid its deposit but at closing asked for an extension on the basis that rezoning had not yet been obtained. British Columbia refused and sued for breach of contract. Cressey defended and argued both frustration and force majeure. ${ }^{186}$

The Court rejected force majeure. ${ }^{187}$ However, it went on to find that the contract had been frustrated. It did so by characterizing the purpose of the contract to be development of the property for sale to the public as residential property. ${ }^{188}$ It is submitted that this characterization was incorrect, and that the real purpose of the contract was the purchase and sale of property as is (that is, not subdivided). The fact that the seller had refused to make the sale conditional on subdivision should have precluded a finding of frustration.

While there is no rule that a contract with a force majeure clause cannot be frustrated, ${ }^{189}$ depending on the facts of the case a force majeure clause can act to preclude application of the doctrine of frustration. For example, in Fishman $v$ Wilderness Ridge at Stewart Creek Inc, a fire caused delay in construction of a condominium unit that was the subject of a purchase and sale agreement. ${ }^{190}$ The seller invoked the force majeure clause, which allowed

\footnotetext{
180 Supra note 105 at para 1.

$181 \quad$ Ibid at paras 26-28.

182 Ibid at paras 69-70.

$183 \quad$ Ibid at para 74.

184 (1992), 66 BCLR (2d) 146 (SC).

185 Ibid at paras 2-4.

$186 \quad$ Ibid at para 5

187 Ibid at para 37. The Court concluded that the Supreme Court of Canada decision in Atlantic Paper required that the force majeure event had to render performance "impossible," based on a portion of Atlantic Paper, supra note 24 at 583 that appears to be obiter dicta. Case law subsequent to Atlantic Paper has not invariably required "impossibility" for a finding of force majeure, and has determined the issue based on the language of the particular force majeure clause at issue. Ibid at para 48.

$189 \quad$ Petrogas Processing Ltd $v$ Westcoast Transmission Co (1988), 89 AR 321 (QB). 
late delivery of the unit in the event of fire. ${ }^{191}$ The buyer argued that the contract was frustrated and that the force majeure clause did not cover frustration. ${ }^{192}$

The Alberta Court of Appeal rejected the argument. In doing so it noted that the force majeure clause anticipated late delivery in circumstances of fire. Because the force majeure clause permitted delayed performance by the vendor, the contract was not incapable of being performed and was therefore not frustrated. ${ }^{193}$

The Court went on to examine the period of delay caused by the fire. The Court stated that whether performance of the contract is so delayed as to amount to frustration is "a matter of degree and context.”" by one year in delivering the completed unit, such delay did not amount to frustration. ${ }^{195}$

Parties have also tried to apply provincial frustrated contracts legislation to cases of force majeure where there were apparent or perceived gaps in the remedy provided for by the contract. Such legislation typically provides for additional remedies in cases of frustration that are not available under the common law. Alberta's Frustrated Contracts Act ${ }^{196}$ appears to allow its remedies to apply to clauses, including force majeure clauses, that are intended to deal with what would otherwise be frustrating events, if the remedies in the Act are consistent with the contractual clause.

Interestingly, the Court in Terpstra, without addressing the interplay between invocation of force majeure and a frustrated contract, or undertaking an express frustration analysis, assumed the contract frustrated and applied the Frustrated Contracts Act ${ }^{197}$ of Newfoundland. ${ }^{198}$ Under the Act the buyer was entitled to recover deposits and any expenses associated with recovering its deposits, although the contract itself did not explicitly contain such a remedy. ${ }^{199}$

\section{IMPACT OF FORCE MAJEURE ClAUSES ON THE Ability to Claim Damages in ANOTHER CASE}

Force majeure issues can arise in unusual ways and sometimes parties find themselves interpreting a force majeure clause in a contract to which they are not parties. This issue has arisen at least twice in the context of "Party A" making a claim against "Party B" for monies A had to pay out in a contract with "Party C" and B arguing that A ought to have claimed force majeure.

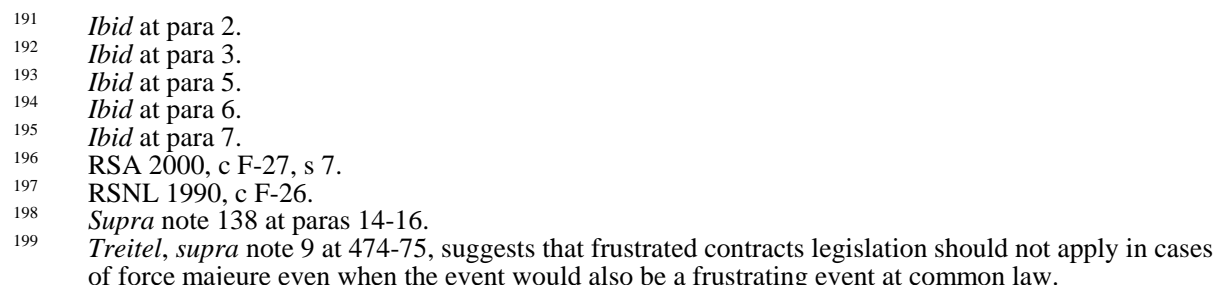


In Matsumoto Shipyards Ltd v Forward Machine Shop Ltd, ${ }^{200}$ Matsumoto Shipyards Ltd (Matsumoto) claimed damages against Forward Machine Shop Ltd (Forward). Forward had agreed to fabricate shafts for Matsumoto. ${ }^{201}$ It failed to do so in accordance with contract. ${ }^{202}$ This caused Matsumoto to be delayed in performing its contract with third party Petroleos Mexicanos (Pemex) to deliver a fireboat at a certain time. Matsumoto had to settle with Pemex, paying penalties under a settlement agreement. As part of its suit against Forward, Matsumoto claimed these penalties. ${ }^{203}$ Forward defended itself, arguing that Matsumoto should have been excused from performance by the force majeure clause in the Matsumoto/Pemex agreement and should not have agreed to pay a penalty to Pemex. ${ }^{204}$ The Court therefore interpreted the Matsumoto/Pemex force majeure clause. It found that Matsumoto was not excused under the force majeure clause. Because Forward was Matsumoto's supplier, not Pemex's supplier, as between Pemex and Matsumoto, it was Matsumoto who had control over Forward's delivery obligations to Matsumoto. As such the failure of Matsumoto's sub-contractor was not an event of force majeure. ${ }^{205}$

\section{CONCLuding Remarks}

Contractual force majeure clauses arose in large part as a response to the perceived limitations of the common law doctrine of frustration. A well-drafted force majeure clause can overcome some of the limitations of frustration by specifying the type of events, and the required impact of those events, that will result in some variance in the parties' contractual obligations. A force majeure clause can also specify the precise effect of the force majeure event on the contract and the parties' obligations, such as suspending the time for performance of obligations or deeming non-performance not to be a breach of a party's obligations. Drafters of force majeure clauses can strive to remove uncertainty about force majeure events by focusing on the key elements of the force majeure clause; namely, the nature of events that will be considered force majeure, the impact that the event must have on the invoking party, and the effect of a force majeure event on the contract and the obligations within it.

See also Frederick Transport Ltd v Gaco Systems, [1988] CLD 162 where the same issue arose but the Court concluded that the defendant could not claim over against the plaintiff for monies paid as a penalty to a third party because it could have relied on a force majeure clause to avoid such payment. 